\title{
Dizer e Viver a esperança Aspectos sobre Linguagem e Religião no pensamento de Rubem Alves
}

Fabiano Veliq ${ }^{1}$

\section{RESUMO}

O tema central deste trabalho é a relação entre linguagem e religião no pensamento de Rubem Alves. Procurou-se evidenciar como se dá a relação entre estes dois conceitos no pensamento do referido autor. Para isso, partiu-se da análise e comparação das principais obras de Alves sobre a questão da religião e evidenciou-se que, para ele, a religião visa garantir um sentido para a existência do homem. Utilizou-se também a análise do debate atual sobre Deus para compreender como essa questão é abordada por Rubem Alves. Percebeu-se que a imagem de Deus enquanto "entidade metafísica" é abandonada no discurso moderno para se tornar uma exigência da interioridade humana. A linguagem sobre Deus não apontaria mais para um "objeto" que estaria lá fora, mas, sim, para o próprio homem. Dessa forma, a religião só pode ser vista como uma linguagem que falará dos anseios deste homem, da esperança desse homem de construir um mundo com sentido. A metodologia utilizada no trabalho é de caráter hermenêutico e tem como eixo a comparação entre as obras de Rubem Alves e o estudo do atual debate sobre a religião na tentativa de elucidar os conceitos de linguagem e religião.

\footnotetext{
1 Fabiano Veliq é doutor em Psicologia pela Pontifícia Universidade Católica de Minas Gerais (PUC-MG).
} 


\title{
PALAVRAS-CHAVE
}

Religião. Linguagem. Esperança. Desejo.

\begin{abstract}
The central theme of this work is the relationship between language and religion in the thought of Rubem Alves. It attempts to show how these two concepts are related to one another. It starts with the analysis and comparison of the major works of Rubem Alves concerning religion, which has made clear that for him religion is meant to ensure meaning for the existence of man. It also deals with the analysis of the current debate about God in order to understand how this issue is addressed by Rubem Alves. We noticed that the image of God as a "metaphysical entity" has been abandoned in modern discourse, and it has become something that human interiority requires. The language about God no longer points to an "object" outside man, but to man himself. Thus, religion can only be seen as a language that speaks of the man's desires and hope in order to build up a meaningful world. The methodology used has a hermeneutic character and its central axis is the comparison between the works of $\mathrm{Ru}$ bem Alves and the study of the current debate on religion in an attempt to elucidate the concepts of language and religion.
\end{abstract}

\section{KEYWORDS}

Religion. Language. Hope. Desire.

\section{Introdução}

Rubem Alves, filósofo e teólogo brasileiro procura pensar a religião no contexto da discussão iniciada por Feuerbach e desenvolvida até Nietzsche. Em sua proposta, Alves argumenta que a religião constitui um grito de esperança em meio ao caos e não está assentada sobre o objeto nem sobre o sujeito, mas se localiza em um ponto anterior, na relação sujeito-objeto. "A religião revela a lógica do coração, a dinâmica do princípio do prazer na medida em que ele luta por transformar um caos não-humano ao seu redor numa ordo amoris"'. O ser humano se vê

2 ALVES, Rubem. O enigma da religião. $6^{\text {a }}$ ed. Campinas: Papirus, 2007, p. 27. 
em um mundo que não lhe pertence e, para tentar escapar deste, cria para si um outro, em que o "princípio de prazer" se sobrepõe ao "princípio de realidade". Este processo de sobreposição se dá por meio da linguagem. O homem que efetua a sobreposição do princípio de prazer sobre o princípio da realidade assume uma nova linguagem, uma linguagem da esperança. $O$ presente artigo mostra o caminho realizado por Rubem Alves para propor uma nova forma de ver a religião.

\section{O corpo e a linguagem}

A linguagem desempenha um papel fundamental na elaboração do conceito alvesiano de religião, pois é por meio da palavra que os mundos são construídos. Isso corresponde a um reviver do mito bíblico em que a partir da palavra divina todas as coisas são criadas. Assim, como afirma Alves, "para se entender a religião, é necessário entender o caminho da linguagem"3.

Podemos notar que a linguagem é algo completamente humano. A diferença feita por Feuerbach entre o homem e o animal no nível da consciência é retomada aqui, acrescentando que o homem também difere do animal por possuir uma linguagem.

$\mathrm{O}$ animal se relaciona com o meio de uma forma direta, adquirindo meios para sobreviver diante da natureza que o cerca. Para isso, reproduz mimeticamente aquilo que seus progenitores faziam. O passado de sua espécie determina como esse animal agirá durante toda a sua vida. Sua interação com a natureza tem em vista sua sobrevivência no mundo, logo, o animal preserva uma memória biológica que lhe possibilita agir sempre da mesma forma. Ele é o seu corpo. Sua programação é fechada, está preso à sua estrutura biológica de forma muito restrita.

Diferentemente do animal, o homem é um ser aberto. Ele é capaz de reprogramar seu passado de forma a agir diferentemente no futuro, pois não há uma relação causal entre o seu corpo e sua atividade.

É possível dizer que o ser humano é aberto ao futuro, já que não é determinado pelo seu passado biológico como o animal. Enquanto este

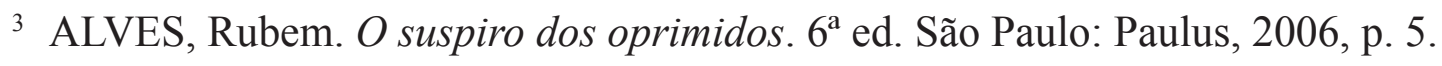


se relaciona com a natureza de forma a tentar se adaptar a ela, o homem age visando transformá-la de forma que ela se adapte às exigências dele. A atividade humana visa sujeitar a natureza às necessidades do corpo humano, da vontade dele, e é por isso que os indivíduos criam os universos simbólicos, religiões, coisas que os animais não fazem nem nunca farão. É a abertura do ser humano ao futuro que lhe possibilita criar o novo.

Como afirma Alves,

Os universos simbólicos, a religião, a história são expressões do esforço humano no sentido de tornar a natureza, o tempo e o espaço em função de si mesmo. Esforço titânico para antropologizar o universo todo, transformando-o numa extensão do corpo ${ }^{4}$.

No entanto, nota-se que o corpo humano não é capaz de fazer grandes coisas. Se comparado ao de outros animais, revela-se como um dos mais frágeis. Em razão disso, o homem precisa inventar meios para conseguir sobreviver diante da natureza. A esses meios, damos o nome de técnica. Esta é, portanto, extensão do corpo, e, nesse sentido, pode-se afirmar que a sociedade é uma técnica inventada pelo homem para sobreviver na natureza. No entanto, ao mesmo tempo em que o homem cria a sociedade, esta dita como ele deverá viver. Segundo afirma Alves,

[...] é a linguagem que faz a sociedade possível e esta torna a linguagem necessária. $\mathrm{O}$ condicionamento de nossa percepção pela linguagem é, realmente, o condicionamento de nossa maneira de ver, ouvir e sentir pela sociedade. Isto significa que nossos mecanismos de interpretação não são mais puramente biológicos, mas sociais ${ }^{5}$.

Diferentemente dos animais, que se relacionam diretamente com a natureza, o ser humano tem a mediação da sociedade, e é ela que ditará o que pode e o que não pode ser feito pelos indivíduos. Para isso, ela cria valores sociais que são mecanismos para interpretação do mundo, o que possibilita a sobrevivência do homem em seu meio. Nesse caso,

\footnotetext{
ALVES, 2006, p. 12.

5 ALVES, 2006, p. 13.
} 
considera-se possuidor de valor apenas aquilo que pode ser tomado como indispensável para a sobrevivência humana.

Se notarmos isso, perceberemos que, como afirma Alves: "todo esforço humano se constitui na tentativa de transformar valores em fatos históricos e sociais. O homem, portanto, quer moldar o mundo, fazendo deste a expressão de seus valores"6.

No entanto, como a relação do ser humano com a natureza é aberta, torna-se necessário que a sociedade que a medeia, enquanto provedora da técnica possa ser reproduzida nas diversas gerações humanas. Por isso surge a linguagem. Esta é inventada em resposta à necessidade de reprodução e manutenção da sociedade, tornando-se uma técnica que possibilita a sobrevivência humana.

Por ser dessa forma, percebe-se que a linguagem determinará como uma comunidade organizará sua ação. A linguagem, portanto, nasce de uma necessidade prática do homem, a saber, da necessidade de sobrevivência frente ao mundo.

Diante do exposto acima, fica claro que a linguagem tem um papel fundamental na definição do real. Como afirma Wittgenstein, "Os limites da minha linguagem denotam os limites do meu mundo" "Ou seja, ela determina a forma como vemos o mundo, organiza-o, coloca-o dentro da estrutura por ela criada. Segundo afirma Alves, "O homem é um construtor de mundos; sua atividade busca criar uma ordo amoris, uma organização que seja expressiva dos seus valores e funcional para a sua sobrevivência"».

O que o homem define como realidade é o que ele organiza. A teoria kantiana do conhecimento já aponta para algo parecido. Pode-se conhecer o que é a coisa para o sujeito cognoscente, mas nunca a coisa em si. E essa coisa organizada pelas estruturas da razão é considerada o real.

Como a linguagem desempenha um papel importante na construção do real, isso permite considerar que as estruturas da razão, postuladas por Kant são, na realidade, a estrutura da linguagem. Esta é um instrumento

\footnotetext{
6 ALVES, 2006, p. 14.

7 WITTGENSTEIN, Ludwig. Tractatus logico-philosophicus. São Paulo: Editora Nacional/Ed. da Universidade de São Paulo, 1968, p. 111. (Biblioteca Universitária. Série 1. Filosofia; 10).

8 ALVES, 2006, p. 18.
} 
social que adquire significado dentro do todo em que é usada. A sociedade que cria determinada linguagem será a responsável por definir o que uma palavra específica significará, assim como definirá o que é real e o que não é.

O segundo Wittgenstein chegou à conclusão de que "o sentido de uma palavra é o seu uso na linguagem", ou seja, uma palavra pode ter significados diferentes dependendo do contexto em que for usada ${ }^{9}$. Não há na linguagem uma relação objetiva entre sujeito e objeto, mas uma mediação entre ambos, uma vez que o mundo humano é organizado e estruturado por meio da linguagem em função dos valores, inspirações e emoções humanas. Esse processo de organização busca criar um mundo significativo para o homem. Ao investigar-se a linguagem, percebe-se que ela remete ao grupo social que a criou, à cosmovisão desse grupo.

Considerando o exposto até o momento, é possível afirmar que a linguagem é a mediadora entre o sujeito e o mundo. O mundo é, portanto, um constructo humano que resulta de um trabalho com a linguagem. Esta ferramenta é indispensável na relação homem-mundo. Afinal, desde a infância, o indivíduo conhece as coisas por meio dela. Como afirma Alves "O homem não vive num universo físico, mas num universo simbólico. Ele não pode defrontar-se com a realidade de forma imediata; não pode vê-la, como se fosse face a face"10. Dessa forma, percebe-se que toda construção do mundo realizada pelo homem necessita da linguagem. Ela é ao mesmo tempo a ferramenta e a estrutura sobre a qual o mundo humano se apoia.

A humanização da natureza é feita pela linguagem, pois o ser humano não lida com a realidade face a face, mas sempre mediado pelas palavras e símbolos. Um mundo sem linguagem torna-se incompreensível para o homem.

Além disso, por meio da linguagem o homem sai do mundo do meramente real (natureza) e entra no mundo do possível (imaginação). No entanto, ela também prende o homem dentro do seu universo de significação. Assim, tem duas funções para a linguagem no pensamento alvesiano. Em primeira medida, ela define os limites do mundo e da atuação

\footnotetext{
9 WITTGENSTEIN, 1968, apud ALVES, 2006, p. 18.

${ }^{10}$ ALVES, 2006, p. 22.
} 
do indivíduo. Porém, por ser definidora da visão de mundo que o indivíduo possa vir a ter, ela também terá um caráter "enfeitiçante" que deverá ser superado pelo homem a fim de que ele possa re-conhecer a estrutura do mundo onde vive.

Para Rubem Alves, a linguagem científica é diferente da linguagem religiosa, aquela descreve o mundo, ao passo que a linguagem religiosa exprime como vive o homem em relação ao mundo. A proposta da fala da religião não envolve a formulação de uma hipótese sobre a existência de Deus, pois Kant já mostrou em sua crítica que tal conhecimento não é possível, envolvendo, antes de qualquer outra coisa, uma paixão subjetiva. A linguagem não é fotografia, como no caso do discurso científico. Alves afirma que o discurso científico pretende fazer de "cada palavra, um reflexo fiel: fazer visível e luminoso o mundo que existe lá fora; falar a verdade, a verdade toda, nada mais que a verdade" 11 . No entanto, a linguagem é interpretação, refletindo a relação entre o homem e o mundo. Como afirma Alves, a linguagem da religião assume outra função, ela pretende falar de outra coisa, de uma relação. Segundo Alves,

[...] as palavras também podem ser objeto de fruição, se nos ligamos a elas pela mesma razão que nos ligamos a um pôr-do-sol, a uma sonata, a um fruto: pelo puro prazer que nelas mora... Brinquedos, fins em si mesmas, palavras que não são para ser entendidas, são comida para ser comida. Caminho da poesia ${ }^{12}$.

Como afirmamos até agora, a linguagem visa à sobrevivência humana frente à natureza. A partir disso, podemos afirmar que toda a luta do homem tem em vista manter o maior valor que existe para ele: a vida. Como afirma Alves,

o animal (inclusive o homem) vê o mundo de acordo com o tipo de relação com a natureza necessária à sua sobrevivência. $\mathrm{O}$ mundo é a natureza organizada do ponto de vista das necessidades de uma espécie, para que ela seja uma continuação natural do corpo ${ }^{13}$.

\footnotetext{
11 ALVES, Rubem. Lições de feitiçaria: meditações sobre a poesia. São Paulo: Loyola, 2003, p. 24.

12 ALVES, 2003, p. 30.

13 ALVES, 2006, p. 24.
} 
Cassirer, em seu ensaio sobre o homem, seguindo Von Uxkell, afirma que cada animal se relaciona com o mundo de uma forma própria. Feuerbach também faz a mesma observação no livro Essência do Cristianismo. De acordo com este último, "se as plantas tivessem olhos, e capacidade para sentir gosto e para julgar, cada uma diria que a sua flor é a mais linda de todas"14. Percebe-se que o homem realiza o contato com o mundo pela mediação da linguagem, o que lhe possibilita a sobrevivência. Para Alves, é o esquecimento desta relação valorativa e funcional da linguagem a causa do dualismo entre a ciência e os valores.

Como afirma Berger,

O homem não possui uma relação preestabelecida com o mundo. Precisa estabelecer continuamente uma relação com ele. A mesma instabilidade assinala a relação do homem com o seu próprio corpo. (...) [A] existência humana é um contínuo pôr-se em equilíbrio do homem com seu corpo, do homem com o seu mundo. O homem está constantemente no processo de pôr-se em dia consigo mesmo. É nesse processo que o homem produz um mundo. Só num mundo assim, que ele mesmo produziu, pode o homem estabelecer-se e realizar a sua vida ${ }^{15}$.

O ser humano se relaciona com o mundo primeiramente de uma forma emocional, pois está diante da natureza com uma necessidade prática, a saber, sua sobrevivência. Logo, ele busca conhecer para sobreviver. Dewey considera que "empiricamente as coisas são comoventes, trágicas, belas cômicas, estabelecidas, perturbadas, confortáveis, desagradáveis, cruas, rudes, consoladoras, esplêndidas, aterrorizantes"16.

Se o homem se relaciona com a natureza de maneira emocional, todo o conhecimento tem que primeiro estar em relação com a necessidade humana mais vital, que é sua sobrevivência. Todo conhecimento tem que permitir a preservação da vida. A linguagem envolve a tentativa de ligar os fatos e os valores criados pela sociedade. Essa relação valorativa

${ }^{14}$ FEUERBACH, Ludwig. A essência do cristianismo. $2^{\mathrm{a}}$ ed. Lisboa: Fundação Calouste Gulbenkian, 2002, p. 20.

15 BERGER, Peter Ludwig. $O$ dossel sagrado: elementos para uma teoria sociológica da religião. $6^{\text {a }}$ ed. São Paulo: Paulus, 2009, p. 18.

16 ALVES, 2006 p. 27. 
é o que faz o homem dar nomes às coisas. $\mathrm{O}$ ato de nomear algo constitui-se como um ato de dar significação às coisas, de organizar o mundo a partir dos valores humanos.

Como afirma Alves, "o segredo da linguagem humana, assim, não é nem a esfera objetiva que ela pode indicar, nem simplesmente estados individuais subjetivos. Ao contrário: é a relação de um sujeito, indivíduo ou comunidade, com um espaço e um tempo"17.

Linguagem, portanto, é relação e relação é valor. Por isso, toda palavra expressa um significado valorizado pelo o homem. À medida que a palavra se aproxima do que tem mais valor para o homem, mais ela se enche de emoção. Essa atitude, no entanto, é anterior à razão. Alves diz que "a atitude valorativa é a mais fundamental no relacionamento do homem com o mundo. E são os valores que criam a necessidade e a possibilidade da razão. A razão é função dos valores"18.

Diante do exposto acima, pode-se notar por que a linguagem deverá remeter sempre ao sujeito, à comunidade que a utiliza. Se o significado da palavra é o seu uso contextualizado e tem esse aspecto valorativo, determinada linguagem dará sempre os valores do grupo que a utiliza. A linguagem falará do homem que a elaborou. Ela dá, portanto, a estrutura dos valores de determinada comunidade.

Aqui, o conceito Wittgensteineano de jogo de linguagem é útil para compreender o papel da linguagem na construção da religião.

\section{O papel da linguagem na construção da religião}

Dada a relação entre corpo e linguagem no pensamento alvesiano, cabe agora tentarmos analisar como esta última desempenha um papel fundamental na construção da religião.

Para Alves, toda religião é um jogo de linguagem. Cada discurso religioso aponta para um grupo que compartilha valores e, por isso, esse discurso estabelece uma visão de mundo que será compartilhada pela comunidade que o utiliza.

\footnotetext{
${ }^{17}$ ALVES, 2006 p. 27.

${ }_{18}$ ALVES, 2006, p. 28.
} 
A religião é uma forma de falar do mundo. Essa forma de discurso é determinada socialmente e transmitida aos novos membros com o intuito de preservar os meios de sobrevivência já conhecidos pela comunidade.

Os jogos de linguagem propostos por Wittgenstein nos mostram que toda linguagem se constitui em um grande jogo. Criam-se regras para que as palavras possam ser usadas e possam possuir determinado significado numa determinada comunidade de tal forma que representem valores para a referida comunidade. Desta forma, ao afirmar a religião como jogo, Alves aponta para a precariedade de toda construção religiosa. Uma vez que a religião se funda sobre a linguagem e que toda linguagem expressa os valores de uma comunidade, chegamos à conclusão que toda religião é um jogo de linguagem que expressa valores humanos.

Para Alves, o homem cria a religião porque quer viver em um mundo que faça sentido. Ele quer transcender a natureza, transformá-la em extensão do seu próprio corpo. E a religião desempenha um papel importante nessa função. Ela é o sonho coletivo de uma determinada comunidade que vê o seu próprio mundo através da linguagem que criou.

Pelo fato de a religião ter na linguagem a sua base, ela só pode ser expressão de valores humanos e, por isso, o falar religioso é carregado de emoção. A religião se liga de forma fulcral à necessidade básica de sobreviver no mundo.

A busca por significado diante da natureza faz o homem elaborar as ideias religiosas de forma que o mundo passe a fazer sentido para além da frieza da realidade.

A religião, portanto, não visa dizer "o que o mundo é”, essa pretensão é científica. Ela procura, antes de qualquer coisa, expressar a relação homem-mundo ou na tentativa de criar um mundo que seja expressão desse próprio homem.

Pode-se perceber que Alves funda a religião sobre um aspecto humanista, assim como Feuerbach, Marx e Freud. A religião é vista como algo completamente humano, como expressão do desejo do homem de viver em um mundo que faça sentido. Nessa perspectiva, o discurso religioso é determinado pelas condições materiais de cada comunidade que se relaciona com a natureza de forma a manter a existência humana. No entanto, a superação proposta por Alves em relação a esses autores se dá através do fato de que, para Alves, que aqui segue Cassirer, o homem não 
é definido apenas como ser racional, mas como ser simbólico. Como tal, ao apelar para a religião, o homem exerce o que há de mais "divino" em si, a saber, seu poder simbólico.

O discurso religioso é expressão do desejo humano, daí ser tão importante para Alves a definição freudiana do homem como ser de desejo. $\mathrm{Na}$ necessidade humana de sentido está a fonte da linguagem, e nesta, a fonte da religião. Ao expressar tal necessidade, o homem é capaz de superar a frieza do real e entrar no mundo do possível. Dessa forma, a linguagem enquanto base da religião dá ao homem o que ele necessita para viver em um mundo com sentido.

Nesse ponto, é muito importante para o pensamento alvesiano o diálogo que ele mantém com as ciências sociais, principalmente com os sociólogos de correntes marxistas, como Peter Berger e Thomas Luckmann. Alves, em seus primeiros escritos sobre religião, assumirá a postura adotada por estes sociólogos e, como eles, afirmará que a religião exerce uma função de manutenção de uma determinada ordem criada.

Mesmo a linguagem sendo aquela que constrói os mundos, nota-se comumente que é muito difícil mantê-los em funcionamento. Berger aponta nessa direção e tenta mostrar que, como toda construção humana, a religião também não está isenta da necessidade de legitimações. Esse autor afirma, em seu livro "O dossel sagrado", que, para esquecer a precariedade da construção do mundo humano e para que o homem não caia em um estado de anomia, a religião constitui uma poderosa força para tornar plausíveis e duradouras as construções sociais da realidade. Isso é feito quando se insere tais construções num mundo mais abrangente, isto é, um mundo sagrado que legitima, justifica e explica as mazelas do cosmos elaborado pelo homem, dando a elas um caráter ontológico que na verdade não possuem.

A linguagem, portanto, cria o mundo, estrutura-o e depois o legitima para que o sentido se conserve diante da ameaça do caos e da desagregação. Dessa forma, a linguagem se constitui como tentativa de conceber todo o universo como humanamente significativo. No entanto, várias vezes, esse significado fica oculto para os indivíduos e a religião passa a ter uma função alienadora.

Se por um lado a religião pode manter esse caráter de tentativa de manutenção da ordem, Alves procurará mostrar que, no final, é a experiência religiosa de cunho estritamente emocional que dá sentido à religião. 
Além disso, Alves indica como a religião pode desempenhar uma função desalienadora que passará pelo âmbito político e terá papel fundamental na construção de uma nova sociedade. Tal função desalienadora só será possível para Alves se a religião deixar de ser vista apenas como uma série de rituais e passe a ser uma ação efetiva no mundo. A crítica proposta por Marx é assumida por Alves sob uma nova perspectiva. Realmente, "a crítica dos céus se transforma em crítica da terra, a crítica da religião se transforma em crítica do direito e a crítica da teologia se transforma em crítica da política" ${ }^{\text {"19. Com }}$ isso, Alves não quer eliminar a religião, como pretende Marx, mas sim mostrar que ela pode e deve desempenhar um caráter transformador do mundo. Esse último é entendido como "dádiva de Deus" e, por isso, o homem, enquanto criatura de Deus, deve se colocar como agente do Seu Reino, visando transformar o mundo. Tal transformação se dará por meio da política. O homem será responsável por trazer o Reino de Deus à terra e isso só será feito se a religião assumir sua função de doadora de significados. Estes não são vazios, nem transcendentes, mas, sim, históricos, pautados na vivência humana. Esta temática é explicitada por Alves em sua dissertação de mestrado e em outros trabalhos posteriores. O tratamento desse ponto, contudo, vai além dos objetivos do presente artigo.

\section{O fenômeno da conversão como mudança de linguagem}

Para se aderir a uma determinada religião, sempre é necessário que haja algum tipo de conversão. Nas sociedades mais primitivas, tal processo é chamado comumente de "rito de passagem". O iniciante é obrigado a passar por uma prova que ateste que ele está pronto para ser encarado como adulto por sua comunidade. Nas comunidades cristãs, acontece a conversão e posteriormente o batismo.

${ }^{19}$ MARX, Karl, ENGELS, Friedrich. Introdução a crítica da filosofia do direito de Hegel. Tradução Artur Morão. Covilhã: Lusosofia Press, 2008, p. 6. Disponível em: $<$ http://www.lusosofia.net/textos/marx_karl_para_a_critica_da_filosofia_do_direito_de_hegel.pdf $>$.Acesso em: 17 jan. 2011. Título original: Zür Kritik der Hegelschen Rechtsphilosophie. 
O processo de conversão, para Rubem Alves, consiste em uma mudança de linguagem.

Alves considera como motivo para a escolha dessa mudança de linguagem a falta de sentido do discurso religioso que ampara uma religião diante do mundo. Para ele, a lógica do cotidiano é a lógica da linguagem. Alves concorda com Wittgenstein em que os limites da minha linguagem denotam os limites de meu mundo. Como toda a humanidade é estruturada pela linguagem, um abalo forte nas estruturas linguísticas faz com que o mundo construído por esta linguagem entre em colapso. Quando isso ocorre, o homem fica sem algo em que se apoiar. A linguagem que legitimava a vida passa a não mais fazer sentido para a consciência humana. O homem entra num estado de anomia, em que se vê diante de uma existência sem sentido, a harmonia entre o eu e o mundo é quebrada. A consciência é uma estrutura de equilíbrio precário. A perda desse equilíbrio leva a uma rebelião do ego e a uma desestruturação do mundo ${ }^{20}$. Como atesta Berger, a religião é uma forma de legitimação que confere um status ontológico às instituições sociais, colocando-as dentro de uma estrutura de referência cósmica sagrada ${ }^{21}$. Quanto à experiência da conversão, o que se vê no seu início é uma crise dos sistemas de referência. Segundo afirma Alves, "o momento de desestruturação da conversão estabelece as bases para a esperança utópica. Ou mais precisamente: por implicar a desintegração dos topoi em que o homem se encontrava, ela torna a visão utópica necessária"22.

Tal visão nos leva a concluir que a conversão consiste em uma tentativa de reestruturar, por meio da imaginação, a harmonia perdida pelo fracasso da linguagem que explicava o mundo vigente. Uma vez acontecido isso, é necessária uma nova forma de explicar a realidade. Neste momento há a conversão. Esta, em qualquer uma de suas formas, é uma tentativa de resgatar o sentido do mundo diante do caos que se instaurou pela perda dos sistemas de referência.

A conversão, portanto, segundo Alves, é uma tentativa de reestruturar a linguagem de forma a tentar viver em um mundo que novamente faça

\footnotetext{
${ }^{20}$ ALVES, 2007, p. 129-131.

${ }^{21}$ BERGER, 2009, p. 57.

${ }^{22}$ ALVES, 2007, p. 136.
} 
sentido. Por isso, converter-se significa mudar de linguagem. Uma vez que essa última estrutura o mundo, ela nos condiciona a vê-lo de acordo com a sua própria estrutura, isto é, ela nos "enfeitiça" e coloca todas as coisas dentro de um quadro de referência. Logo, uma alteração brusca nesse quadro fará com que o homem mude a sua forma de ver o mundo.

Converter-se a uma religião, para Alves, é aceitar o novo discurso proposto por uma comunidade religiosa e abandonar o discurso antigo que passou a não mais fazer sentido. Converter-se é uma tentativa de reestruturar, por meio da adoção de uma nova linguagem, a ordem da consciência. É uma tentativa de fazer com que a ordem prevaleça sobre o caos.

Cabe ressaltar que Alves compreende que tal experiência de conversão não é um processo racional, já que não é uma experiência objetiva, mas subjetiva diante do mundo. As coisas permanecem como eram antes, a relação entre o sujeito e a realidade é que se transforma. Nesse momento, ocorre um milagre, através do qual a consciência ressuscita transfigurada, sem causa natural. Ela tem uma visão de um mundo que é novo, mas que é o mesmo.

Alves afirma que tal mudança de linguagem não tem no sujeito sua causa eficiente, i.e, ele não é o agente da transformação. É um milagre. Segundo o autor,

o homem que passou pela experiência da iluminação sabe apenas de uma coisa: não foi ele a causa eficiente, o sujeito dessa transformação. Não foi o poder de sua impotência que gerou a sua força. Seu poder vem de uma fonte que não é o seu eu. Não nasce do seu interior, como liberação de energia ali acumulada. Ao contrário, tudo se passa como se ele tivesse sido repentinamente apanhado por um torvelinho de poder que lhe é exterior ${ }^{23}$.

A nova forma de ver e pensar o mundo nascem sem o auxílio de processos conscientes. Uma vez que a consciência está desestruturada, não há como emergir dela uma nova realidade, mas algo exterior é que deverá promover tal transformação. Isso leva a uma conclusão que Alves mesmo considera contraditória: "Atinge-se o resultado quando se abandona

${ }^{23}$ ALVES, 2007, p. 154. 
a esperança de alcançá-lo. Resolve-se o problema quando se desiste de resolvê-lo. Ganha-se o poder quando se desiste de procurá-lo"24.

Alves afirma que o homem que passou pela conversão não consegue explicar como tal mudança se deu, mas sabe apenas que ela ocorreu. Tal passagem do estado de anomia para o de encontro com o sentido é inexplicável por meio da linguagem. A experiência religiosa é inefável. Sobre ela, não há um discurso que possa evocar uma relação causal entre a anomia e a descoberta de sentido, somente se constata que o novo homem vê o mundo com novos olhos. Alves afirma que "a nova experiência lhe foi dada. Veio de fora. Milagre. Criação do Espírito"25. Não há, portanto uma mediação lógica para tal processo.

O autor considera que a experiência da conversão atesta o caráter precário e provisório dos modelos teóricos humanos para compreender a realidade. Para ele, há uma descontinuidade entre o racional e o real. A realidade é mais complexa do que pensamos. Não nos encontramos sobre um plano unidimensional que pode ser projetado ad infinitum, mas antes no ponto de interseção de uma infinidade de planos que se interrompem, que se negam, que se superam. Não é possível, portanto, manter-se a idéia de uma realidade totalmente previsível, racional $^{26}$.

Como se pode notar, o colapso da lógica introduz uma dimensão misteriosa na experiência religiosa. Ela se apresenta como uma nova maneira de ser em relação ao mundo, uma relação que não pode ser descrita pela lógica da linguagem uma vez que tal realidade lhe escapa.

O conteúdo do processo envolvido é pessoal e existencial, tem a ver com a maneira de ser do indivíduo diante do mundo. Para Alves,

a experiência da conversão, com vestes religiosas ou não, é uma possibilidade permanente aberta ao homem e como tal, um sintoma da permanente inquietação que nos caracteriza existencialmente e da permanente precariedade do mundo em que habitamos. (...) O homem se caracteriza pelo seu "cor inquietum"27.

\footnotetext{
${ }^{24}$ ALVES, 2007, p. 155

${ }^{25}$ ALVES, 2007, p. 157.

${ }^{26}$ ALVES, 2007, p. 158.

27 ALVES, 2007, p. 162.
} 
O homem marcado pelo cor inquietum é o ser que busca o sentido diante da realidade. É aí que a conversão, essa metamorfose, dá a esse ser a possibilidade de agir de maneira diferente diante do mundo. Alves afirma que tal metamorfose se opera pela mágica da imaginação. E como esta é derivada da emoção, a experiência religiosa primordial é fundamentalmente emotiva.

Por esse motivo, para Alves, o ideal científico de objetividade seria algo anti-humano, uma vez que o homem se define como ser de desejo, ser que busca o sentido, ser que, através da linguagem, procura, acima de tudo, a sobrevivência. Todo conhecimento deve ser movido pela paixão, afinal na emoção se revela a maneira de ser do indivíduo em relação ao mundo e de o mundo colocar-se em relação com ele.

Alves adotará a postura adotada por Rudolf Otto, que converge com a de Wittgenstein, propondo que tal experiência religiosa é inefável. Segundo ele, "a experiência do divino é a experiência de uma nova forma de consciência que se constitui não autonomamente sobre si mesma, mas antes sobre um transcendente que ela mesma não contém"28.

A experiência do divino é vista então como uma nova forma de consciência constituída sobre um transcendente que se encontra "fora" dessa consciência. A experiência da conversão, no pensamento Alvesiano, coloca o homem diante desse outro que o transcende, mas este último, paradoxalmente, não se apresenta como totalmente transcendente. Esse outro, várias vezes é percebido como Deus. No entanto, o conceito de Deus em Alves sofre bastantes mudanças com o passar do tempo.

\section{A linguagem que pretende falar sobre Deus}

Se percorrermos a obra de Rubem Alves, desde os seus primeiros escritos, notaremos que a questão de Deus sempre está presente. $\mathrm{O}$ autor mantém a reflexão sobre Deus em seus escritos, mas altera muito o olhar lançado sobre Ele.

Em sua dissertação de mestrado, Alves aponta para Deus enquanto transcendente ao homem, uma visão mais clássica que coloca esse

${ }^{28}$ ALVES, 2007, p. 160, 161. 
ser divino como criador e mantenedor de todas as coisas. Deus, nesta primeira fase, seria "totalmente outro", transcendente e diferente do homem. Alves, neste momento, está extremamente influenciado por seus estudos teológicos e dá a Deus um caráter transcendente que se aproxima daquele da visão cristã. Tal visão aqui exposta vai contra a interpretação de Gouveia Franco ${ }^{29}$, para quem Alves não tem esta visão transcendente de Deus nem em seus primeiros escritos. Percebe-se que Franco não leva em conta a dissertação de Alves, mas considera os textos deste último a partir do livro 'Da esperança'. Se, na interpretação do pensamento de Alves, for levada em conta a sua dissertação, a imagem de um Deus transcendente se fará presente de uma forma muito intensa, principalmente no último capítulo da mesma.

Nos escritos posteriores, provavelmente devido ao contato com Feuerbach, Marx, Nietzsche e com as ciências sociais, Deus passa a desempenhar outra função. Alves passa a ver Deus não mais como um ser transcendente ao homem, mas como algo que deriva deste, por ser expressão máxima do desejo e, em última instância, da esperança última do homem.

Alves argumenta que a "morte de Deus" é um problema antropológico que ocorre em uma sociedade que assumiu o discurso científico como único discurso possível ${ }^{30}$. Se nos basearmos na causalidade natural, como faz a ciência, concluiremos que a linguagem de Deus é impossível. Mas se nos basearmos na subjetividade humana, veremos que a linguagem de Deus é necessária. Neste tipo de sociedade não há lugar para o Deus metafísico. Este Deus enquanto "entidade metafísica" é abandonado no discurso moderno. Para Alves, foi o existencialismo que criou um novo lugar para Deus, mas Ele não é o mesmo. Com efeito, nos pensadores existencialistas teístas, como Kierkegaard, Deus deixa de ser uma entidade metafísica e passa a ser uma exigência da interioridade humana ${ }^{31}$. A linguagem sobre Deus não aponta mais para um "objeto" que estaria lá fora, mas sim para o próprio homem. Nessa perspectiva, os assassinos de Deus são seus novos profetas ${ }^{32}$.

${ }^{29}$ FRANCO, Sergio Gouveia. The concepts of liberation and religion in the work of Rubem Alves. Vancouver, 1987, p. 23. Tese não publicada.

30 ALVES, 2007, p. 61.

${ }^{31}$ ALVES, 2007, p. 73.

32 ALVES, 2007, p. 78. 
O mesmo homem que antes tenta dar sentido à vida através da ciência constata que ela não é capaz de responder a seus anseios. A experiência do absurdo se instaura e sobre este assunto o discurso científico não pode falar. A "morte de Deus" envolve a impossibilidade de falar: sobre o que não se pode falar, deve-se calar. Depois da "morte de Deus", Ele passa a ser símbolo da relação Eu-Mundo. "Deus nasce como expressão de uma relação. [...] A palavra Deus não se refere nem ao $\mathrm{Eu}$ e nem ao Mundo, mas antes ao hífen, à relação invisível que os une" ${ }^{\prime 3}$.

A situação do homem diante de Deus passa a ser descrita de forma paradoxal: a ausência de Deus é a única forma de sua presença; crer em Deus é viver como se Ele não existisse - no entanto, a coragem está em afirmar o sentido apesar de.

Essa coragem silenciosa emerge das profundezas obscuras do ser, não deriva da fé em Deus, mas persiste apesar da "morte de Deus". Essa coragem é a fé absoluta. Fé que não se relaciona a nenhum objeto. Deus desaparece enquanto objeto para se assumir enquanto esperança ${ }^{34}$.

Deus, portanto, é visto como esta ânsia pela busca de um sentido para a existência. Deus se transforma em horizonte que o homem vislumbra. Diante do silêncio, da "morte de Deus", resta apenas a esperança. Como afirma Alves:

Deus desaparece como objeto. [...] Mas sua presença continua de forma mais estranha, porque ela se anuncia numa consciência de ausência, na saudade de um bem-amado que nos deixou ou que ainda não veio. E a consciência de Deus como objeto se transforma em esperança: não uma consciência de algo, mas no simples tender da consciência para um imenso vazio que a enche de nostalgia. Nas linhas de Ernst Bloch, temos então de afirmar que onde quer que exista a esperança, ali existe a religião, porque aí se revela a nossa nostalgia pelo Reino de Deus, o grande projeto utópico que a humanidade não cessa de sonhar mesmo quando, de olhos abertos, ela não tenha condições de ver ${ }^{35}$.

\footnotetext{
${ }^{33}$ ALVES, 2007, p. 65.

${ }^{34}$ ALVES, 2007, p. 81.

${ }^{35}$ ALVES, 2007, p. 82.
} 
O homem que "mata Deus" sente a necessidade de colocar algo em seu lugar e Deus retorna, passando agora a ser o símbolo da esperança ou, nas palavras de Alves:

Ora, o que é Deus? O símbolo da plausibilidade dos meus valores, a promessa da salvação, a realidade onipotente dos meus anseios, o poder da minha fraqueza. Deus é o símbolo da esperança: a esperança corporificada na imaginação. Destituída a esperança, morrem os deuses. Destituídos os deuses, morre a esperança ${ }^{36}$.

Percebe-se que Deus não habita o lugar dos discursos, a fala sobre Deus está interditada. Resta o silêncio apenas, no máximo uma teologia negativa. Mesmo assim, Ele assume outra forma, assume a forma da esperança, que fará com que a religião deixe de ser um inventário de coisas celestes e passe a ser uma atitude em relação ao mundo, visando transformar as condições de existência. Deus enquanto símbolo da esperança é aquele que motiva o homem a ser de uma forma diferente diante do mundo. Não importa mais o que se fala sobre Deus, mas sim como se vive no mundo recebido com dádiva de Deus.

Percebe-se que falar sobre Deus é falar sobre os desejos desse homem. Por isso, todo discurso sobre Deus nada mais é que um discurso sobre o ser humano.

Percebe-se uma semelhança muito grande com Feuerbach nesse ponto. No entanto, há uma diferença entre o pensamento alvesiano e a proposta feuerbachiana.

Feuerbach coloca Deus como objetivação humana. Em suas preleções sobre a essência da religião, esse autor tenta mostrar que Deus nada mais é que um ser imaginário, uma entidade da fantasia, e, como a fantasia, é aquilo sobre o qual a poesia se baseia. Pode-se assim dizer: "a religião é poesia, um Deus é um ser poético"37.

Alves concorda com Feuerbach quando este afirma que refletir sobre Deus é refletir sobre o homem e também quando apresenta Deus

\footnotetext{
${ }^{36}$ ALVES, 2007, p. 145.

${ }^{37}$ FEUERBACH, Ludwig. Preleções sobre a essência da religião. In: SOUZA, Draiton Gonzaga de. O ateísmo antropológico de Ludwig Feuerbach. 2a ed. Porto Alegre: EDIPUCRS, 1994, p. 153.
} 
como ser poético. De acordo com Alves, Deus pode sim ser visto dessa forma, pois, na poesia, o que está em jogo também é a tentativa de exprimir o inexpressável. Se Deus é poesia e a poesia é expressão do desejo humano, Deus pode ser tomado como forma de realizar essa expressão. Em Alves a religião também é poesia, embora revele algo humano: os desejos do coração humano, assim como a esperança do homem diante da vida. Encarar a religião como poesia faz com que se evitem os dogmatismos, uma vez que sobre ela não recairá a pergunta sobre a verdade ou a falsidade. Falar sobre Deus é sempre fazer poesia, é expressar desejos de um mundo melhor para os indivíduos. Encarar Deus como poesia é encará-lo como expressão humana. No entanto, assim como em Marx, em Alves não haveria uma "essência humana" independente das condições materiais. O homem é determinado pelas condições materiais, e como qualquer discurso sobre Deus é, na verdade, sobre o ser humano, tal discurso aponta também para a sociedade em que esse homem está inserido.

Deus não é mais visto como ser transcendente, mas como horizonte a que todo indivíduo tende. Deus assume então a mesma função de uma esperança utópica a ser concretizada na terra. Ele irá se associar de forma direta ao desejo de criar uma ordo amoris, um mundo que faça sentido. Para que tal objetivo ocorra, é preciso que a religião desempenhe outro papel, o de construir uma ordem social que possibilite ao homem viver essa esperança.

O reino de Deus assume uma dimensão não-transcendente, mas completamente imanente e social. É, portanto, um reino político, em que a justiça social prevalece e o homem retorna ao Éden ${ }^{38}$.

A linguagem que quer falar sobre Deus, falará sobre justiça social, sobre condições materiais dignas para os indivíduos, sobre a esperança de viver em um mundo que faça sentido. Não será uma linguagem capaz de abarcar o transcendental, mas será uma prática visando fazer com que o homem retorne ao Éden.

Nesse sentido, Alves, ao refletir sobre Deus, não se refere a um ser transcendente, mas a um ser que age na história do homem e que é expressão deste.

${ }^{38}$ ALVES, 2003, p. 140,141. 


\section{Como aponta Cervantes-Ortiz,}

o deus da religião não se entende nem se vive racionalmente; de fato há tantos deuses, sem a possibilidade de se harmonizarem, quanto religiões; eles são "hipóteses vitais", "sintomas de uma imensa variedade de projetos de vida", motivo pelo qual se revela impossível dizer qual é o verdadeiro. O discurso religioso surge do corpo do ser humano, de cada homem/mulher, de sua unicidade absoluta ${ }^{39}$.

Com o passar do tempo, o discurso alvesiano sobre Deus passa a ser um discurso sobre o corpo. Numa entrevista concedida a Buenfil, Alves esclarece:

Uma questão que posteriormente ficou, ou tornou-se importante para mim, foi a questão do corpo. Compreendi que todas as lutas que se travam tem a única finalidade de fazer com que o corpo seja feliz. Não há absolutamente nada no mundo mais importante que o corpo. Se nós fazemos a revolução, a única finalidade da revolução é permitir que os corpos não tenham medo, que possam dormir em paz, que possam trabalhar em paz, que possam criar o amor, que possam ter seus filhos. Que possam viver o futuro sem medo, sem angústias. Então, meu pensamento sobre Deus transformou-se realmente em um pensamento sobre a libertação do corpo. Além disso, para os cristãos, o mais alto símbolo religioso que existe é o símbolo da ressurreição do corpo. Ressurreição do corpo significa ao menos duas coisas, liberdade e dignidade. São para mim os dois valores mais elevados da religião cristã ${ }^{40}$.

O corpo, esquecido pelo discurso teológico, é retomado por Alves, que o coloca como centro do discurso sobre Deus. Este é posto como esperança para o corpo. É relevante dizer que o corpo aqui não é entendido como uma estrutura biológica, mas sim como algo construído culturalmente por meio da linguagem. Como afirma Nunes,

${ }^{39}$ CERVANTES-ORTIZ, Leopoldo. A teologia de Rubem Alves: poesia, brincadeira e erotismo. Campinas: Papirus, 2005, p. 152.

40 VÁZQUEZ BUENFIL, Luis. "Rubem Alves y la teologia del cuerpo" In: CERVANTES-ORTIZ, Leopoldo. A teologia de Rubem Alves: poesia, brincadeira e erotismo. Campinas: Papirus, 2005, p. 171. 
o corpo vive assim uma tensão permanente entre o assédio do passado, dos símbolos herdados, presentes nas bibliotecas, museus, monumentos e as vozes do futuro que emergem no mais profundo de nossas entranhas, indicando caminhos novos. Ele é uma encruzilhada de discursos, uma instância de negociação permanente, de resolução e criação de conflitos, de alegria e de dor. Ele é ao mesmo tempo passado e futuro, memória e esperança. $\mathrm{O}$ corpo é o centro do universo ${ }^{41}$.

É através do corpo que Deus se manifesta ao homem, garantindo a possibilidade da esperança. Esperança material que se realiza no futuro. Projeto utópico do homem.

Dessa forma, percebe-se que a visão alvesiana sobre Deus sofre uma alteração com o passar do tempo. De um Deus transcendente, Alves passa à visão de Deus como horizonte para a concretização dos desejos humanos. Tal realização só é possível a partir do resgate da significação do corpo como a parte mais importante do ser humano, uma vez que é através dela que o homem se faz ser-no-mundo.

\section{A religião como linguagem da esperança}

Tendo em vista o que foi exposto acima, cabe agora ressaltar como a religião pode ser encarada como linguagem da esperança no pensamento alvesiano.

Já foi visto que a religião é linguagem, uma forma de falar sobre o mundo, e nessa fala o que está em jogo é o desejo humano de viver em um mundo que faça sentido, a tentativa de antropologizar o mundo. No entanto, para que isso aconteça, é preciso que o ser humano seja movido por algo. Esse algo que o move na construção da religião é a esperança.

O conceito de esperança adotado por Alves é ligado a uma "teoria da realidade". Segundo Alves:

Esperança é uma teoria da realidade: uma suspeita de que os valores, mesmo na sua não-existência fatual presente, são mais reais que os

${ }^{41}$ NUNES, Antonio Vidal. A ciência e o homem no pensamento de Farias Brito e Rubem Alves. Vitória: EDUFES, 2007, p. 207, 208. 
fatos imediatamente dados. Esperança é a suspeita de que o que é importante agora se revelará como poderoso no futuro. É uma rejeição do positivismo. Por isso o homem é capaz de enfrentar a dor e o sofrimento. Ele os vive como acidentes provisórios, a serem conquistados no futuro. Enquanto permanecer a esperança, a estrutura da personalidade permanecerá também. Quando, entretanto, a esperança entra em colapso, a personalidade se desintegra. Porque o colapso da esperança é o meso que reconhecer os valores como ilusões e a brutalidade dos fatos sem sentido como realidade. Só lhe resta então entregar-se às estruturas de poder do seu tempo-presente, que são a negação dela mesma ${ }^{42}$.

Há, como se pode ver, uma relação íntima entre esperança e realidade vivida. A esperança é uma tentativa de negar o presente dado, uma tentativa de rebeldia contra a dor e o sofrimento.

Tal temática se identifica com o de Ernst Bloch e outros expoentes do pensamento marxista, tais como Leszek Kolakowski e Karl Mannheim. Destes autores, Alves retirará a idéia de esperança que norteia seu pensamento, estabelecendo o Reino de Deus como o lugar utópico.

A esperança, tanto em Bloch quanto em Alves, vincula-se ao projeto utópico entendido como o eterno sempre presente. Segundo Gerardo Cucino, em Bloch

a filosofia utópica busca uma via alternativa, interpretando a realidade humana e cósmica como um processo de autoprodução do essencial que se move na direção de um lugar (ainda) inexistente (u topos) que deveria, ao mesmo tempo, revelar-se como o lugar do viver bem (eu topos), ou seja, justamente o novum de um ser satisfeito e justificado, dotado de sentido ${ }^{43}$.

Percebe-se que a filosofia utópica se volta para o futuro ainda inexistente, buscando fundar, a partir da práxis, uma nova dimensão para a vivência humana. Essa nova vivência tem de se colocar, de forma inevitável, contra o status quo.

${ }^{42}$ ALVES, 2007 p. 145.

${ }^{43}$ CUCINO, Gerardo. Messianismo ateu como meta-religião. In: GIORGIO Penzo; ROSINO, Gibellini (orgs.). Deus na filosofia do século XX. $2^{\mathrm{a}}$ ed. São Paulo: Loyola, 2000, p. 263-264. 
Pode-se notar que a filosofia utópica mantém uma relação muito próxima com o pensamento religioso. E isso não apenas pelo fato de conter em si uma filosofia da religião devido à presença de uma consciência utópica, mas também por realizar uma interpretação antropologizante e crítico-religiosa das tradições religiosas, de forma a possibilitar a classificação destas como religiões humanístico-subversivas ou religiões teocrático-conservadoras. A filosofia utópica, nesse sentido, apresenta-se como meta-religiosa, ou seja, ela constitui a autoconsciência e ao mesmo tempo a ultrapassagem da religião tradicional, de forma a possibilitar o retorno do mistério à existência.

A síntese proposta por Bloch entre marxismo e cristianismo é algo que influenciará bastante o pensamento alvesiano. Cucino afirma que

o marxismo genuíno leva, porém, a sério o cristianismo genuíno, e a isso não contribui um mero diálogo em que os pontos de vista sejam abrandados e tornados conciliadores; pelo contrário: se do lado cristão ainda é visada realmente a emancipação dos fracos e oprimidos, se do lado marxista a profundidade do reino da liberdade se torna e permanece realmente como conteúdo substancial da consciência revolucionária, então a aliança entre revolução e cristianismo na guerra dos camponeses não terá sido a última, - e desta vez com sucesso ${ }^{44}$.

Pode-se notar em Bloch que tanto o marxismo quanto o cristianismo devem ir além de suas figuras atuais, já cristalizadas. É preciso que se redescubram e atualizem seu impulso originário, que é o impulso para a libertação total e para a realização das esperanças humanas.

Segundo afirma Cucino,

Bloch vê o manifestar-se específica e autenticamente religioso desse impulso num peculiar movimento do transcender como ultrapassagem radical fundada numa esperança mais forte do que todas, ou melhor, no totum de uma esperança que põe o mundo inteiro em relação com uma perfeição inteira. (...) Nesta "utopia da perfeição", buscada de modo intransigente como tensão escatológica para o reino da vida autentica, Bloch descobre a "essência" da religião,e também o

\footnotetext{
${ }^{44}$ CUCINO, 2000, p. 265.
} 
seu substrato tão insuprimível quanto digno de ser "herdado" também por uma esperança que não confie mais numa salvação transcendente. A "utopia do reino" age como núcleo genuíno em todas as religiões, mas encontra sua expressão mais direta e explícita no messianismo judaico e em seu paradoxal prolongamento cristão ${ }^{45}$.

Em Bloch, o Reino de Deus enquanto núcleo último da esperança humana necessita da rejeição do Deus transcendente e ao mesmo tempo da rejeição de toda divindade posta como entidade fundante. A eliminação do próprio Deus como ens realissimum seria condição para a totalidade da esperança, uma vez que, presente, Ele tolheria a abertura dos indivíduos para o futuro e impediria a ação criativa deles. Enquanto essa perspectiva se mantiver, o futuro se colocará de forma fechada para o homem. Por isso, Deus enquanto ens realissimum precisa ser eliminado.

A esperança em Bloch é vista então como algo completamente humano que só será realizado com a participação da classe trabalhadora humanizando o mundo. A esperança, portanto, visa a uma nova realidade que supere o presente. O que é não pode ser verdade, e por isso a esperança é o móbile da ação humana para mudar o status quo que aprisiona o homem.

Em seu livro Da esperança, tese de doutorado defendida em Princenton em 1968, Alves parte da definição do ser humano como ser histórico. Por possuir tal atributo, ele é capaz de se abrir para o futuro de forma a tentar construir um mundo que seja humano. Na primeira frase de sua tese, Alves afirma:

O homem é um ser histórico. Ele não nasce no mundo das coisas, das pessoas e do tempo como um produto acabado. Seu ser não preexiste à história. Torna-se o que é através da história de suas relações com o meio ambiente. Não é, por conseguinte, apenas um ser no mundo: torna-se um ser com o mundo. Homem e mundo não se juntam como duas entidades estranhas que estão eventualmente numa relação de contato, como se fosse uma mente ou ego que simplesmente notasse aquilo que se lhe contrapõe, ou seja, matéria ${ }^{46}$.

$\overline{{ }^{45} \text { CUCINO, 2000, p. } 266 .}$

${ }^{46}$ ALVES, Rubem. A Gestação do futuro. $2^{\mathrm{a}}$ ed. Campinas: Papirus, 1987, p. 45. 
O homem é um ser aberto, e é isso que lhe possibilita ter esperança, que o coloca no reino da liberdade. Além disso, é essa liberdade que the permite nomear as coisas de forma que seu contato com o mundo seja mediado pelo desejo humano e não por uma imposição. Tal nomeação é feita por meio da linguagem, ela nomeia os objetos do desejo. Daí o fato de ser ela algo fundamental na construção do conceito alvesiano de religião. Segundo afirma Alves:

A linguagem do homem constitui um espelho de sua historicidade. Ela não emerge simplesmente do metabolismo que se dá entre o ser humano e o mundo, mas é proferida como uma resposta às situações concretas. É óbvio que linguagem nem sempre consiste na expressão da historicidade humana. [...] Quando a linguagem é histórica, no entanto, ela conta a história humana, o que não implica uma simples descrição. Ela contém a interpretação humana da mensagem e do desafio que este lança ao mundo, afirmando o que acredita que seja a sua vocação, o seu lugar, as suas possibilidades, a sua direção e a sua função no mundo ${ }^{47}$.

Desde seus primeiros escritos, o autor já enfatiza o caráter histórico da linguagem, já que ela participa da interpretação do mundo feita pelo homem na tentativa de dar sentido à realidade. A linguagem só cumpre esse papel por ser histórica, aberta, capaz de criação, pautada na esperança. De acordo com Nunes,

O que Alves percebeu [...] é que uma nova linguagem estava surgindo como parte de um processo histórico em que ele apenas contribuía para ela se tornar visível. Era um novo discurso que expressava a dor e os anseios de povos, comunidades, minorias que se sentiam explorados e feridos em suas dignidades. [...]

Mas a nova linguagem somente poderia surgir como expressão de um homem que sofresse no presente, mas soubesse que a ordem dada não poderia ser definitiva. Quando o presente lhe fosse amargo e a consciência voltasse sobre si mesma, recusaria o status quo e buscaria no futuro de possibilidades adequadas e desejadas. Nisso, o homem realizaria a sua liberdade. Motivado pela esperança, ele correria

\footnotetext{
47 ALVES, 1987, p. 46.
} 
atrás do amanhã, o que implicaria sempre um ato político, atividade para a qual o homem tem vocação enquanto criador de história, dinamizado por uma imaginação engajada ${ }^{48}$.

Pode-se observar como os conceitos de história, de liberdade, de linguagem e de corpo se interligam no pensamento alvesiano. Neste, a esperança parte da consciência do homem diante de sua situação histórica, a qual, por ser como é, não pode permanecer no estado em que se encontra. A crença no futuro melhor nasce da insatisfação humana com a condição atual da realidade ${ }^{49}$. Esta dinâmica se efetiva de forma muito mais clara na figura dos oprimidos, dos pobres, do proletariado. Dessa forma, a dinâmica da negação é completamente histórica e secular. A história é determinada pela negação e pela esperança. Negação das condições atuais que desumanizam o ser humano e esperança de que, no futuro, as condições sejam outras. Segundo Alves:

O presente é negado porque o homem, vivendo nela (história), apreende tudo aquilo que cria a dor, o sofrimento, a injustiça e a ausência de futuro da história. Devido ao presente ser historicamente doloroso e, portanto, desumanizante, ele tem de ser negado. A esperança não se deriva de uma idéia a-histórica a respeito de uma sociedade perfeita; ela constitui, ao contrário, a forma positiva assumida pela negação do presente inumano e negativo. A insatisfação da consciência não se origina da percepção de um padrão apriorístico, anterior à percepção dos fatos e, por isso, eterno, mas sim de seu desacordo com o modelo de futuro obtido a partir de sua percepção da presente realidade. A consciência, assim, parte da história e para ela permanece voltada ${ }^{50}$.

Quando o homem se descobre como sujeito histórico, ele se vê como alguém que pode gerar um novo amanhã, encontrando assim a sua humanidade. A criação da história, como apontado por Alves, é possível somente por meio do poder, uma vez que é por meio do exercício histórico do poder que se pode negar o inumano e abrir-se para um futuro mais humano. Mas, como afirma o autor,

\footnotetext{
${ }^{48}$ NUNES, 2007, p. 196-197.

49 ALVES, 1987, p. 46-47.

${ }^{50}$ ALVES, 1987, p. 59.
} 
o emprego do poder é um ato político. Por isso, a nova consciência acredita que um novo homem e um novo amanhã só serão criados por meio de uma atividade caracteristicamente política. A política seria, assim, a prática da liberdade, uma atividade do homem livre com o intuito de criar um novo amanhã. Nesse contexto, a política não mais é entendida como uma atividade de poucos, como um jogo de poder das elites. Antes, ela consiste na vocação do ser humano, pois todos são chamados a participar, de uma forma ou de outra, na criação do futuro ${ }^{51}$.

Com isso percebe-se que o falar sobre Deus é falar sobre a esperança humana. Logo, a religião enquanto linguagem será a linguagem da esperança humana. A religião passa a assumir então, no pensamento alvesiano, a função de ser transformadora da sociedade, ela será agente da transformação do mundo, uma vez que se vê como tentativa de expressão do maior desejo humano.

\section{Conclusão}

Percebe-se que a linguagem religiosa, no pensamento alvesiano, abre-se para a esperança e para a tolerância. Esperança de ver um mundo melhor no futuro e tolerância ao reconhecer a precariedade de nossas construções, que se apoiam sobre algo tão frágil como a linguagem. Nessa perspectiva, a religião enquanto linguagem é um horizonte que se oferece ao homem em sua tentativa de viver o mundo com sentido.

Enquanto a ciência constitui um fator de legitimação da ordem social, a religião constitui um fator crítico da realidade, enquanto a ciência sacraliza o dado, a religião é um protesto contra essa sacralização, buscando uma ordem não dada através da esperança. Por isso, a religião pode ser entendida como linguagem da esperança no pensamento alvesiano.

$\overline{{ }^{51} \text { ALVES, 1987, p. } 60 .}$. 


\section{Referências Bibliográficas}

ALVES, Rubem. O enigma da religião. $6^{\text {a }}$ ed. Campinas: Papirus, 2007. ALVES, Rubem. A Gestação do futuro. $2^{\mathrm{a}}$ ed. Campinas: Papirus, 1987. ALVES, Rubem. Da esperança. Tradução do inglês por João Francisco Duarte Jr. Campinas: Papirus, 1987. Título original: Towards a theology of liberation.

ALVES, Rubem. Lições de feitiçaria: meditações sobre a poesia. São Paulo: Loyola, 2003.

ALVES, Rubem. O suspiro dos oprimidos. 6 ed. São Paulo: Paulus, 2006. ALVES, Rubem. Protestantismo e repressão. São Paulo: Ática, 1979.

ALVES, Rubem. Sobre o tempo e a eternidade. Campinas: Papirus, 1995. ALVES, Rubem. Uma interpretação teológica do significado da revolução no Brasil [1963] Tradução de Antonio Vidal Nunes e Carlos Felipe Tavares. Redes - Revista Capixaba de Filosofia e Teologia. Vitória, Edição especial, 2004.

BERGER, Peter Ludwig. O dossel sagrado: elementos para uma teoria sociológica da religião. $6^{\text {a }}$ ed. São Paulo: Paulus, 2009.

CERVANTES-ORTIZ, Leopoldo. A teologia de Rubem Alves: poesia, brincadeira e erotismo. Campinas: Papirus, 2005.

CUNICO, Gerardo. Messianismo ateu como meta-religião. In: GIORGIO Penzo; ROSINO, Gibellini (orgs.). Deus na filosofia do século $X X .2$ ed. São Paulo: Loyola, 2000.

FEUERBACH, Ludwig. A essência do cristianismo. $2^{\mathrm{a}}$ ed. Lisboa: Fundação Calouste Gulbenkian, 2002.

FEUERBACH, Ludwig. Preleções sobre a essência da religião. In: SOUZA, Draiton Gonzaga de. O ateísmo antropológico de Ludwig Feuerbach. 2a ed. Porto Alegre: EDIPUCRS, 1994.

FRANCO, Sergio Gouveia. The concepts of liberation and religion in the work of Rubem Alves. Vancouver, 1987. Tese não publicada.

MARX, Karl, ENGELS, Friedrich. Introdução a crítica da filosofia do direito de Hegel. Tradução Artur Morão. Covilhã: Lusosofia Press, 2008, p. 6. Disponível em: <http://www.lusosofia.net/textos/marx karl_para_a_critica_da_filosofia_do_direito_de_hegel.pdf $>$. Acesso em: 17 jan. 2011. Título original: Zur Kritik der Hegelschen Rechtsphilosophie. 
NUNES, Antonio Vidal. A ciência e o homem no pensamento de Farias Brito e Rubem Alves. Vitória: EDUFES, 2007.

VÁZQUEZ BUENFIL, Luis. "Rubem Alves y la teologia del cuerpo". In: VAZQUEZ BUENFIL, Luis; PÉREZ ALVAREZ, E. Fe Cristiana, teologia protestante, iglesia y misiónen América Latina. México: Cupsa, 1987, p. 24-25. (Entrevista) In: CERVANTES-ORTIZ, Leopoldo. A teologia de Rubem Alves: poesia, brincadeira e erotismo. Campinas: Papirus, 2005.

VIEIRA, Antonio Rufino. Princípio esperança e a herança intacta do marxismo em Ernst Bloch. Disponível em: $<$ http://www.unicamp.br/ cemarx/anais_v_coloquio_arquivos/arquivos/ comunicacoes/gt1/sessao6/Antonio_Rufino.pdf.> Acesso em: 15 nov. 2010.

WITTGENSTEIN, Ludwig. Tractatus lógico-philosophicus. São Paulo: Editora Nacional: Ed. da Universidade de São Paulo, 1968. (Biblioteca universitária. Série 1. Filosofia;10)

Submetido em: 14/05/2014 Aceito em: 06/06/2013 